Preposterous to brood so late into love and at such distance ("falling" thirty-two feet per second per sec-). A few uncalledfor words hurrying across the continent via Schenectadys of circumlocution, already outraced by a punctual globe, a handspin shy of darkness or the long face of rain (whence breaks a rumbling, neither of disconsolate god, nor arpeggio come tardy of illumination). How far into notion the words spill, tailing the lightning stab of innuendo across a protracted gape-infinite bones to pick, infinite points of departure riddling the heart.

\title{
WEATHER AT SEA
}

—for Donald Justice

The night is black as only night can be, And quiet, like a rain that's ceased to fall. The fishing boats go out upon the sea.

A boatman turns his salt-burned face alee And blinks his eyelids, eyelids of a doll. The night is black as only night can be.

The night is black and dreamlong like a key Turned, and turned again, and then let fall. The fishing boats go out upon the sea.

Dark the corridors down which they flee. Still the water, weary sleeper's shawl. The night is black as only night can be. The fishing boats go out upon the sea. 